\title{
"The impact of the COVID-19 pandemic on retailer performance: empirical evidence from India"
}

\begin{tabular}{|c|c|}
\hline \multirow{5}{*}{ AUTHORS } & Amgad S.D. Khaled (D https://orcid.org/0000-0003-0040-3849 \\
\hline & Nabil Mohamed Alabsy iD https://orcid.org/0000-0002-9443-1738 \\
\hline & Eissa A. Al-Homaidi iD https://orcid.org/0000-0002-6230-8276 \\
\hline & \multirow{2}{*}{$\begin{array}{l}\text { R https://publons.com/researcher/3578411/eissa-a-al-homaidi/ } \\
\text { Abdulmalek M.M. Saeed (D https://orcid.org/0000-0002-7941-5780 }\end{array}$} \\
\hline & \\
\hline ARTICLE INFO & $\begin{array}{l}\text { Amgad S.D. Khaled, Nabil Mohamed Alabsy, Eissa A. Al-Homaidi and } \\
\text { Abdulmalek M.M. Saeed (2020). The impact of the COVID-19 pandemic on } \\
\text { retailer performance: empirical evidence from India. Innovative Marketing, 16(4), } \\
\text { 129-138. doi:10.21511/im.16(4).2020.11 }\end{array}$ \\
\hline DOI & http://dx.doi.org/10.21511/im.16(4).2020.11 \\
\hline RELEASED ON & Tuesday, 22 December 2020 \\
\hline RECEIVED ON & Friday, 20 November 2020 \\
\hline ACCEPTED ON & Friday, 18 December 2020 \\
\hline & $(\mathrm{cc}) \overline{\mathrm{EY}}$ \\
\hline LICENSE & $\begin{array}{l}\text { This work is licensed under a Creative Commons Attribution } 4.0 \text { International } \\
\text { License }\end{array}$ \\
\hline JOURNAL & "Innovative Marketing " \\
\hline ISSN PRINT & $1814-2427$ \\
\hline ISSN ONLINE & $1816-6326$ \\
\hline PUBLISHER & LLC “Consulting Publishing Company "Business Perspectives” \\
\hline FOUNDER & LLC "Consulting Publishing Company "Business Perspectives" \\
\hline & 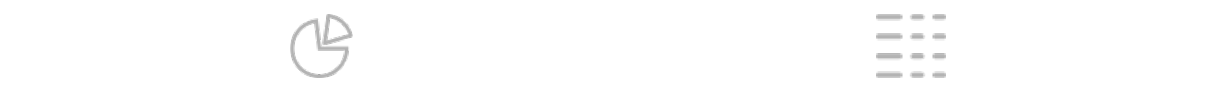 \\
\hline NUMBER OF REFERENCES & NUMBER OF FIGURES \\
\hline 45 & 7 \\
\hline
\end{tabular}

(C) The author(s) 2022. This publication is an open access article. 


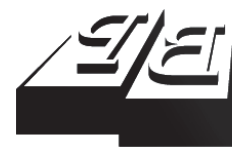

\section{BUSINESS PERSPECTIVES}

LLC "CPC "Business Perspectives" Hryhorii Skovoroda lane, 10, Sumy, 40022, Ukraine www.businessperspectives.org
Received on: $20^{\text {th }}$ of November, 2020 Accepted on: $18^{\text {th }}$ of December, 2020 Published on: 22 ${ }^{\text {nd }}$ of December, 2020

(C) Amgad S.D. Khaled, Nabil Mohamed Alabsy, Eissa A. Al-Homaidi, Abdulmalek M.M. Saeed, 2020

Amgad S.D. Khaled, Ph.D., Assistant Professor, Faculty of Management, Department of Management Information System, Al-Rowad University, Yemen.

Nabil Mohamed Alabsy, Ph.D., Assistant Professor, College of Business, Department of Business Administration, University of Bisha, KSA.

Eissa A. Al-Homaidi, Ph.D., Research Scholar, Department of Commerce, Aligarh Muslim University, India. (Corresponding author)

Abdulmalek M.M. Saeed, M.COM, Student, Department of Commerce, Aligarh Muslim University, India.
This is an Open Access article, distributed under the terms of the Creative Commons Attribution 4.0 International license, which permits unrestricted re-use, distribution, and reproduction in any medium, provided the original work is properly cited.

Conflict of interest statement: Author(s) reported no conflict of interest

Amgad S.D. Khaled (Yemen), Nabil Mohamed Alabsy (KSA),

Eissa A. Al-Homaidi (India), Abdulmalek M.M. Saeed (India)

\title{
THE IMPACT OF THE COVID-19 PANDEMIC ON RETAILER PERFORMANCE: EMPIRICAL EVIDENCE FROM INDIA
}

\begin{abstract}
The study aims to synthesize the challenges that retailers are facing during the COVID-19 emergency. The research is definitive, informative, and based on a single design of cross-sectional research. Quantitative data based on the research instrument were produced (a questionnaire). Five hundred responses were collected from employees of major retail stores in India. Retailer performance is considered a dependent variable, whereas employee well-being, customer and brand protection, use of technology, government policies, and supply chain are used as independent variables. The current study results indicated that employee well-being and government policies have a significant positive impact on retailer performance, while customer and brand protection, use of technology, and supply chain have a significant positive impact on retailers' performance. This study will help retailers develop strategies for their employees to protect them and understand that technology is needed in the new normal times. This study highlights the need to be flexible in executing strategic strategies, but retailers need to develop comprehensive action plans, including selecting managers of initiative and defining goals and deadlines. Provided that retailers' current reality is different from the old normal, no time is lost in taking audacious action.
\end{abstract}

Keywords

JEL Classification India

M31, M39

\section{INTRODUCTION}

The retail market of India has over 15 million retailers, both small and large, both conventional and new. Retail hires between 40 and 50 million Indians, with more than six million Indians directly employed through international commerce, contributing almost 12 percent of the country's overall retail consumption. Retail improves roughly. The shutdown to deter the spread of coronavirus in India affected retail businesses significantly - $40 \%$ of the Indian intake and $10 \%$ of the Indian GDP. Most of the stores were shut throughout the country, except stores selling essential food and medicine. Almost all shops have closed down clothes, saris, electronics, cell phones, furnishings, equipment, etc. The revenue decline of non-grocery/food stores is 80 to $100 \%$. However, distributors selling essential goods face risks if they cannot market non-essential goods, meaning that they have better profits. During the pandemic during an economic recession, Indian retailers, especially non-essential products such as clothing and jewelry, were affected (income hit by $75 \%$ by the end of March 1). With most national officials halting their operations, many shops are either completely closed or still operating grocery stores. India's $40 \%$-contributed retail sector was affected by COVID-19 in the amount of $\$ 30$ billion over two weeks ended on April 1,2020, as given by the CAIT. The 
company had declined by the end of February 2020 to 20-25\%, according to the Retailers Association of India (RAI). It has now decreased to 15 percent over the last month and a half.

Indian retailers will need to develop strategies to reduce the disturbance caused by the COVID-19 crisis, 'next' and 'done.' Retailers will urgently focus on managing vital market practices and retaining respect inspired the large workforce. When retailers are adapting to the fluidity of "here," they need to create "next" resilience as the competition starts to recover and "believe". They should simultaneously plan for long-term impacts on a strategic journey towards financial resilience. No one will, with certainty, estimate the financial effect of this situation on the market with the constantly changing COVID-19 pandemic. The actual effect and recovery will depend on the recession time and the level of behavior. Nonetheless, it will check both distributors and those who can respond financially stable, flexible, and responsive employees.

The COVID-19 pandemic (started in early 2020) triggers many short- and mid-term disruptions for companies to adapt. Some retailers responded to the emergency immediately, displaying a variety of different forms of action. The article aims to understand the reaction of the workers to COVID-19 in the retail sector. The retail sector has taken measures to protect the health of workers. The retail sector aims to adapt to technological developments to make it easier for both staff and consumers. The retail industry follows government guidelines. The study found that employee well-being and government policies significantly and positively impact retailer performance, while customer and brand protection, use of technology, and supply chain have a significant positive impact on retailer performance. This review identified a need to be agile in implementing strategic initiatives, but retailers need to develop detailed action plans, including selecting initiative managers and the specification of targets and deadlines. Given that the new reality of retailers is different from the old standard, no time is wasted in taking bold action.

\section{LITERATURE REVIEW AND HYPOTHESES}

In the hope of minimizing deaths in various ways but with significant adverse effects for national economies, industries, and individual workers, India had locked-up wide segments of its markets. Estimates of economic effects are early in many countries, but some developing markets are considered significant and even catastrophic (Evans, 2020). The Chinese economy is expected to have reached 3.2 percent in 2020 (Fernandes, 2020), a couple of months or so more than other nations. For the US, GDP growth will decrease in the course of its 1.5 -month containment strategy by 2.9 percent in 2020 (Fernandes, 2020; Makridis \& Hartley, 2020). Fernandes (2020) is projected that in the case of a moderate lockout (1.5 months), GDP growth in most countries will decline by between three and five percent by 2020 . An additional two to $2.5 \%$ of global GDP growth occurs each month of the shutdown. The retail, hospitality, and touristic sectors will be especially affected (Dolnicar \& Zare, 2020) and the hospitality and tourism industries (Fernandes, 2020). More jobs at risk will impact more service-driven markets (Fernandes, 2020). China suggests that the "return to normality" will be followed by a rapid uptick in demand due to market demands, but the turnaround can be confined to a very short-term effect (Deng et al., 2020) restoring the usual rate of psychological anticipation in retail environments.

Nevertheless, the COVID-19 pandemic is global, and since World War II, the democracy of people has not been subject to such drastic restrictions as those imposed by previous democratization regimes, adopted by certain countries (e.g., Italy) full shutdown tactics. In contrast, others restricted the number and activities of companies and utilities (e.g., UK), while others implemented security measures that substantially restrict citizens' right to leave home. Such initiatives seriously affected the daily lives of customers and businesses; reduced tourism led to emergency buying situations (EPS) (Somason \& Voyer, 2014) and posed unparalleled retail management challenges. Consumers naturally go shopping differently due to extraor- 
dinary controls. The "scarcity effect" (Hamilton et al., 2019) has had a dramatic impact on-demand elasticity and storage practices, whereas conventional dissuasions such as "waiting times and perceived crowding are now accepted", as evidenced by long queues entering shops. Many supermarket retailers distribute food availability messages and restrict the number of products to purchase per customer, introduce new forms of online services and home delivery, but often with unsatisfactory results for customer well-being.

The latest research has substantially affected customer preference due to the perceived lack of goods (Hamilton et al., 2019). While the literature accepts that scarcity increases the usefulness of the inaccessible good (Verhallen \& Robben, 1994), the shortage of capital leads either to a relative increase in the worth of the scarce goods or to a decrease in the quality of the purchasing sense (Shah et al., 2015). However, the continued loss of brands (because of inventory outages) and shops (because they shut down) could exacerbate customer habits, ultimately impacting the option of commodity shares long after shops return to normal. Panic has also increased the price response of customers. Several determinants of the demand elasticity of goods have been extensively studied in previous literature (Huang et al., 2017; Wakefield \& Inman, 2003). The lengthy waiting times in an emergency are not expected to have a negative effect on customer loyalty with the shops. Nevertheless, it is not clear whether the consequences of condition variables remain over time. For example, customer satisfaction with the time spent waiting comes from the contrast with the length of the queue (Kumar, 2005).

The reduced efficiency of the facilities, combined with higher safety issues for customers, has resulted in a growing need for alternate supply sources. Unforeseen laws that enforce social isolation have a huge effect on the preferred shopping platform of consumers. Specifically, although there has been steady but limited growth in online shopping in the last decade (Harris et al., 2017), the COVID-19 emergency has seen online foods grow. For, e.g., retailers like Ocado (UK) and Carrefour (France) have been compelled to allow online queues or use the platforms digitally to meet unsustainable demand (Mintel, 2020). Social isolation is a social exclusion process that adversely affects consumers' health (Dennis et al., 2015; Papagiannidis et al., 2017). Concerns about the effects of COVID-19 on, for example, anxiety, stress, and depression (Holmes et al., 2020), but at least partly online shopping could reduce the negative influence of social isolation (Dennis et al., 2015; Papagiannidis et al., 2017). Besides, counter-measures between retailers and policymakers that contribute to greater adoption of biometric authentication (e.g., body scan, facial recognition, GPS tracking, etc.), which may also impact expectations of privacy over time. Biometrics are used and divulged to induce users to fret about their safety, though with cultural variations (Miltgen et al., 2016; Carpenter et al., 2016).

Some stores like Ted Baker (UK) have received support alerts, either to remind buyers that they are sending them home notifications and passwords or to temporarily close all shops (limiting internet purchases only) while allowing shoppers to be healthier and healthier, such as Louis Vuitton, Paul Smith, and Mulberry. The alteration in buying patterns triggered by an incident is one of the most affected by luxury retailers (Tsai, 2006). Others have introduced new behaviors that wish to be especially socially involved in this development and have specifically indicated they matter about society (Janssen et al., 2017). For instance, Ralph Lauren donated 10 million dollars to the World Health Organization, and other luxury stores such as Armani and Ferragamo donated to Italian hospitals and charities. Bulgari has switched their manufacturing to hand sanitizers, while Ferrari and Dyson have manufactured fans and other instruments for hospital patients and have even reconfigured their factories to produce medicinal clothing. Although prior research has emphasized how to prioritize the adoption of modern in-store technology to enhance the customer's experience (Pizzi et al., 2019; Vannucci \& Pantano, 2019), retailers are working on enhancing online offerings and home delivery.

To cope with the demand and pressure from the COVID-19 emergency, it is recommended that retailers concentrate on the following key areas: new competitive capability needs to be "built to meet the changing demands of customers and pressures on the governments to handle businesses" (Schriber \& Lowstedt, 2019). An agile approach to shifts in demand and vendor responses (Sjodin et al., 2020; Gordon et al., 2020) may minimize the lead- 
time. This requires retailers to understand how they interact with their partners (i.e., consumers, suppliers, staff, etc.). This would reduce reaction times and streamline processes. More coordination with stakeholders is required to make them feel part of the process rather than just vendors or end consumers (e.g., demanding input during operation).

These universal values and the shared intention of being able to bring customers benefit imply heterogeneous retail practices. However, perhaps to prevent being viewed as alien or disconnected from reality (Tsai, 2006), others have introduced new behaviors that wish to be especially socially involved in this development and have specifically indicated they matter about society as Janssen et al. (2017) have anticipated. In a previous study, the launch of new in-storage technology to improve customers' experience (Pizzi et al., 2019; Vannucci \& Pantano, 2019) stressed how to gain value. However, retailers' eeforts are heading towards enhancing online shopping and distribution at homeland.

The study aims to understand the employee's response to COVID-19 in the retail sector. The retail industry has been taking measures to protect the employees' health. The retail industry is trying to adapt to technological changes to make things easier for the employees and the customers. The retail industry is following government guidelines. The following hypotheses were formulated for a more in-depth and thorough study of the set goals:

$H_{0 a}$ : There is no significant difference between employee well-being and retailer performance during the COVID-19 pandemic.

$H_{o b}$ : There is no significant difference between customer and brand protection and retailer's performance during the COVID-19 pandemic.

$H_{o c}: \quad$ There is no significant difference between the use of technology and retailer performance during the COVID-19 pandemic.

$H_{0 d}:$ There is no significant difference between the government's guidelines and retailer performance during the COVID-19 pandemic.
$H_{0 e}$ : There is no significant difference between supply chain and retailer performance during the COVID-19 pandemic.

\section{METHODS}

The data are collected from 500 employees of the organized retail sector in India. The data are collected from the employees of Spencer, Big Bazaar, Future group, and Reliance Retail. A questionnaire was used for data collection. The Likert scale of five points, which ranges from strongly agreed to disagree, measured two major proportions, including the impact of COVID-19 on the retail sector and employees of the retail sector. Each variable had a certain set of questions. The paper aims to know whether there is a significant difference between the impact of COVID-19 and the retail industry of India. SPSS version 23 was used for the data processing, and all experiments were performed in a 5 percent sense standard. Descriptive figures identified the key demographic characteristics of the survey.

There have been 500 absolute and open responses collected from various regions in India. The above table shows that the male respondents were higher than the females. The majority of the customers were in the age group of 20-30 years old. The respondents were senior secondary graduates. The employees had 5-10 years of association with the particular store.

Table 1. Demographics of respondents

\begin{tabular}{|c|c|c|}
\hline Variable & $\begin{array}{c}\text { Total } \\
\text { responses }\end{array}$ & Percentage \\
\hline \multicolumn{3}{|c|}{ Gender } \\
\hline Male & 261 & 52.20 \\
\hline Female & 239 & 47.80 \\
\hline \multicolumn{3}{|c|}{ Age } \\
\hline $20-30$ & 220 & 44.00 \\
\hline $30-40$ & 178 & 35.60 \\
\hline $40-50$ & 102 & 20.40 \\
\hline \multicolumn{3}{|c|}{ Education } \\
\hline Senior secondary & 195 & 39.00 \\
\hline Diploma & 173 & 34.60 \\
\hline Graduate & 122 & 24.40 \\
\hline Postgraduate & 10 & 2.00 \\
\hline \multicolumn{3}{|c|}{ Years of association } \\
\hline $0-5$ years & 193 & 38.60 \\
\hline $5-10$ years & 256 & 51.20 \\
\hline More than 10 years & 51 & 10.20 \\
\hline
\end{tabular}




\section{RESULTS}

\subsection{Kaiser-Meyer-Olkin (KMO)}

The KMO method is used to check the suitability of the sampling for the EFA (Barrett et al., 2011). The KMO value for sampling adequacy is expected to be greater than 0.50 as per Ferry and Leech (2005). The KMO value is 0.674 , according to Table 1. Therefore, the sample size of this study is adequate to perform both the EFA and other tests. To check the relation between the variables (Tobias \& Carlson, 1969), Bartlett's test of sphericity is also applied. Bartlett's test of sphericity should be relevant $(p<0.001)$, according to Tobias and Carlson (1969). Table 1 reveals that the value after Bartlett's test of sphericity is 0.000 .

Table 2. KMO and Bartlett's test

\begin{tabular}{|c|c|c|}
\hline \multicolumn{3}{|c|}{ KMO and Bartlett's test } \\
\hline \multicolumn{2}{|c|}{ Kaiser-Meyer-Olkin measure of sampling adequacy } & .674 \\
\hline \multirow{3}{*}{ Bartlett's test of sphericity } & Approx. Chi-squared & 9511.704 \\
\hline & df & 666 \\
\hline & Sig. & .000 \\
\hline
\end{tabular}

\subsection{Total variance explained}

As shown in Table 3 , the six constructed factors explained 78.483 of the total variances. The six factors explain about $51.454 \%$ of the variance. The second factor explains about 63.464, third factor explains about 68.717 , fourth and fifth factors represent 72.653 and $3.980 \%$, respectively, and the last factor explains about 78.483. Table 3 also shows that the total variance explained (TVE), and it can be observed that the eigenvalue for the first factor is good, i.e., 11.145, and the cumulative total variance explained for all the variables was 78.483 .

Table 3. Total variance explained

\subsection{Exploratory Factor Analysis}

Factor analysis is the main focus of data reduction and definition analysis. This mathematical method helps to reduce the number of correlated variables independently. The relationship between many different variables can be analyzed using a set of underlying dimensions known as factors or parameters. Exploratory Factor Analysis (EFA) was used to incorporate less of the variables or factors of the original variables to improve the definition.

Table 4. Exploratory Factor Analysis

\begin{tabular}{|c|c|c|}
\hline No. & Items & Extraction \\
\hline 1 & $\begin{array}{l}\text { Planning long term optimization in payroll- } \\
\text { related expenses (such as bonus, increment) }\end{array}$ & .662 \\
\hline 2 & $\begin{array}{l}\text { Planning ways to attract talent through } \\
\text { innovative HR policies when demand picks } \\
\text { up in case layoffs have taken place }\end{array}$ & .539 \\
\hline 3 & $\begin{array}{l}\text { Planning for implementation of permanent } \\
\text { health and safety measures in stores to } \\
\text { reinforce customer trust }\end{array}$ & .626 \\
\hline 4 & $\begin{array}{l}\text { Identifying and preparing for demand } \\
\text { tailwinds like Diwali and marriage season }\end{array}$ & .697 \\
\hline 5 & $\begin{array}{l}\text { Long-term modernization of essential } \\
\text { technology infrastructure to ensure } \\
\text { continuity of business }\end{array}$ & .626 \\
\hline 6 & $\begin{array}{l}\text { Improving digital protection and mitigating } \\
\text { the possibility of data theft, disinformation, } \\
\text { and malware }\end{array}$ & .544 \\
\hline 7 & $\begin{array}{l}\text { Seeking continued government support } \\
\text { through industry representation }\end{array}$ & .790 \\
\hline 8 & $\begin{array}{l}\text { Managing supply chain disruption of } \\
\text { essentials (grocery, packed foods, home } \\
\text { care) due to production shutdown, } \\
\text { restriction on truck movement while } \\
\text { meeting unprecedented spike in demand }\end{array}$ & .537 \\
\hline 9 & $\begin{array}{l}\text { Store closures and a significant drop } \\
\text { in demand for non-essentials (apparel, } \\
\text { lifestyle) leading to inventory pile-up of the } \\
\text { current season and expected arrival of next } \\
\text { season stock }\end{array}$ & .686 \\
\hline
\end{tabular}

As shown in Table 4, nine items test different structures under analysis.

\begin{tabular}{|c|c|c|c|c|c|c|c|c|c|}
\hline \multirow{2}{*}{ Component } & \multicolumn{3}{|c|}{ Initial eigenvalues } & \multicolumn{3}{|c|}{$\begin{array}{l}\text { Extraction sums of squared } \\
\text { loadings }\end{array}$} & \multicolumn{3}{|c|}{$\begin{array}{c}\text { Rotation sums of squared } \\
\text { loadings }\end{array}$} \\
\hline & Total & $\begin{array}{c}\% \text { of } \\
\text { variance }\end{array}$ & $\begin{array}{c}\text { Cumulative } \\
\%\end{array}$ & Total & $\begin{array}{c}\% \text { of } \\
\text { variance }\end{array}$ & $\begin{array}{c}\text { Cumulative } \\
\%\end{array}$ & Total & $\begin{array}{c}\% \text { of } \\
\text { variance }\end{array}$ & $\begin{array}{c}\text { Cumulative } \\
\%\end{array}$ \\
\hline 1 & 19.038 & 51.454 & 51.454 & 19.038 & 51.454 & 51.454 & 11.145 & 30.121 & 30.121 \\
\hline 2 & 4.444 & 12.01 & 63.464 & 4.444 & 12.01 & 63.464 & 6.461 & 17.463 & 47.584 \\
\hline 3 & 1.943 & 5.253 & 68.717 & 1.943 & 5.253 & 68.717 & 3.629 & 9.807 & 57.391 \\
\hline 4 & 1.456 & 3.936 & 72.653 & 1.456 & 3.936 & 72.653 & 2.834 & 7.66 & 65.051 \\
\hline 5 & 1.119 & 3.026 & 75.678 & 1.119 & 3.026 & 75.678 & 2.677 & 7.234 & 72.284 \\
\hline 6 & 1.038 & 2.805 & 78.483 & 1.038 & 2.805 & 78.483 & 2.294 & 6.199 & 78.483 \\
\hline
\end{tabular}




\subsection{Reliability analysis}

Nunnally (1967) describes the measures as precision, while the explanation for the mistake is some influence differentiating between measurement situations. Reliability means how a system achieves comparable outcomes continuously. Based on the total reliability considered for each element (Hogan, Benjamin, \& Brezinski, 2000), Cronbach's alpha is a typical reliability metric. A wide-scale indicates the value of Cronbach's alpha greater than 0.7 (Hair et al., 2010). The Cronbach's alpha value surpassed the amount agreed for every structure, as seen in Table 5 .

Table 5. Cronbach's alpha

\begin{tabular}{l|c|c}
\hline \multicolumn{1}{c}{ Construct } & $\begin{array}{c}\text { Cronbach's } \\
\text { alpha }\end{array}$ & $\begin{array}{c}\text { Overall Cronbach's } \\
\text { alpha }\end{array}$ \\
\hline Employee well-being & .876 & \\
\hline $\begin{array}{l}\text { Customer and brand } \\
\text { protection }\end{array}$ & .743 & \\
\hline Use of technology & .701 & .763 \\
\hline Government policies & .839 & \\
\hline Supply chain & .700 & \\
\hline
\end{tabular}

The validity of a system testing what is predicted is stated. An integration and exclusion will determine the utility of the procedure. Inter - item analysis of correlation follows convergent validity. As previous researchers suggested, the correlation values between the sample areas were 0.6 to 0.9 (Kalafatis, 2004). Psychometric scale tests thus ensured the intensity and reliability of the unit. The results show that Cronbach's alpha is the most reliable factor. The value is generally shown to be 0.6-0.8 highly reliable.

\subsection{Confirmatory Factor Analysis}

Variables are incorporated into EFA variables, research being confined to factor loads, cross loads, and independence section. Lee et al. (2008) recommended that a Confirmatory Factor Analysis be carried out to resolve this cap set in EFA, which contains all variables in the CFA model after the Exploratory Factor Analysis and reliability evaluation. CFA is a study of factors that measures a direct correlation between latent variables underlying data and the structural hypothesis (Field, 2009). The CFA is a hypothesis-based technique in which the hypothesis establishes a relationship between the unknown and measurable variables. A theory is verified or denied by CFA. Following the covariance observed, the proposed model is used for estimating population covariance. The model is used to approximate covariations and interrelationships between latent houses. CFA is a valuable method for evaluating abstract logic (Reise et al., 1995).

Table 6. CFA results

\begin{tabular}{l|c:c}
\hline Fit index & $\begin{array}{c}\text { Recommended } \\
\text { value }\end{array}$ & Value \\
\hline Chi-squared/df & $<3.0$ & 1.19 \\
\hdashline GFI & $>.80$ & 1.20 \\
\hline AGFI & $>.80$ & .901 \\
\hline RMSEA & $<.07$ & .001 \\
\hline CFI & $>.80$ & 2.91 \\
\hdashline RMR & $<.01$ & .000 \\
\hline
\end{tabular}

\subsection{Hypotheses testing results}

Regression was used to test the relationship between different constructs of the proposed model. In regression, the maximum likelihood method was used for testing the hypotheses. The study has used regression to test the causal relationship between the COVID-19 pandemic and retailer performance.

The findings in Table 7 show that three significant hypotheses and two non-significant hypotheses are supported. $H_{O a}$ shows a direct impact of employee well-being on retailer performance $(\beta=0.456, p=.000)$. $\beta=456$ indicates that employee well-being affects the dependent variable retailer performance by about 45 percent. Therefore, a 1 percent increase in employee well-being will result in a 45 percent improvement in retailer performance. The $p$-value $(p=0.000)$ reveals the positive and direct relationship between employee well-being and retailer performance. Table 7 shows the regression analysis result used to determine the impact of customer and brand protection and retailers' performance during the COVID-19 pandemic. The result shows the impact is positive (coefficient $=0.041)$. Further, this impact is statistically significant. Therefore, $H_{0 b}$ is not acceptable. 


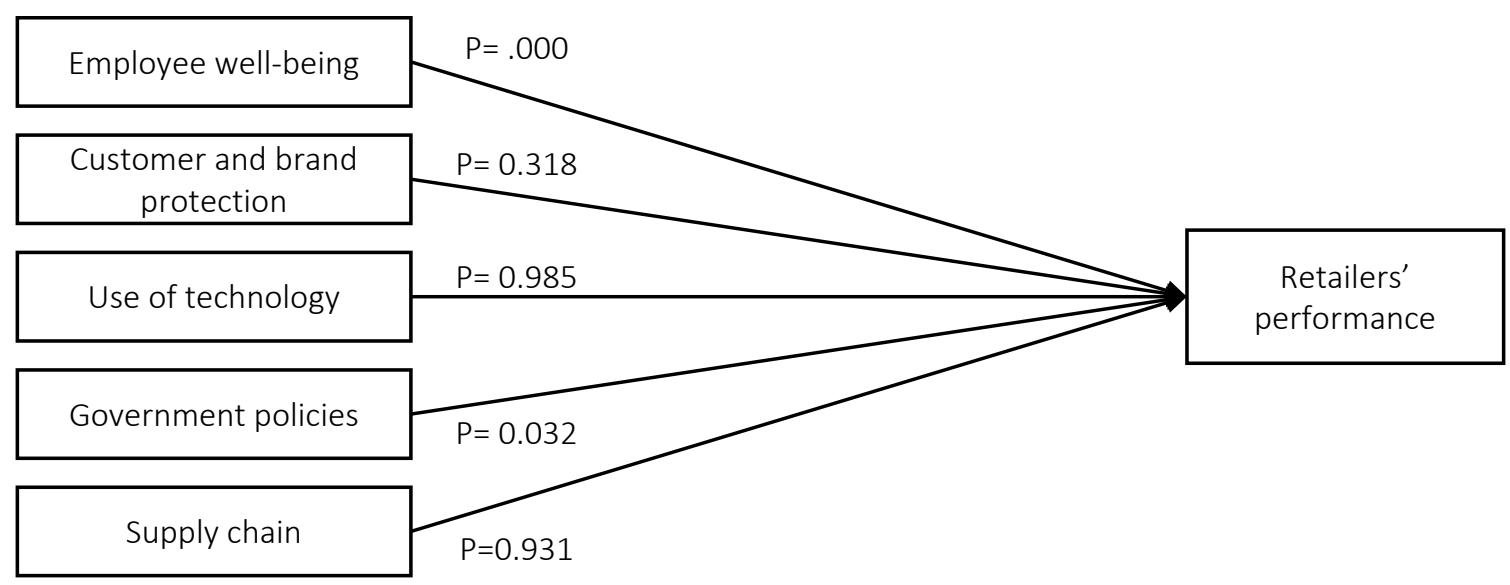

Figure 1. Regression model

Table 7. Regression analysis

\begin{tabular}{|c|c|c|c|c|c|}
\hline No. & Independent variable & Dependent variable & Coefficient & Sig. & Result \\
\hline 1 & Employee well-being & \multirow{5}{*}{$\begin{array}{l}\text { Retailer } \\
\text { performance during } \\
\text { COVID } 19\end{array}$} & 0.456 & 0.000 & Sig. \\
\hline 2 & Customer and brand protection & & 0.041 & 0.318 & Insig. \\
\hline 3 & Use of technology & & 0.008 & 0.985 & Insig. \\
\hline 4 & Government policies & & 0.872 & 0.032 & Sig. \\
\hline 5 & Supply chain & & 0.002 & 0.931 & Insig. \\
\hline
\end{tabular}

The regression analysis outcome was used to classify the impact of the use of technology and retailers' performance during the COVID-19 pandemic. The result shows the impact is positive (coefficient $=0.008$ ). Further, this impact is statistically significant. Therefore, $H_{0 c}$ is not acceptable. The result also shows that there is no significant difference between government policies and retailers' performance. The result shows a positive impact. Hence $H_{o d}$ is acceptable. The table shows a significant difference between supply chain and retailers' performance during the COVID-19 pandemic. The result shows that the impact was positive. $H_{0 e}$ is not acceptable.

\section{DISCUSSION}

More than 15 million retailers in the Indian retail industry are small and large, traditional and new. Retail directly employs 40-50 million Indians, of whom modern trade employees more than 6 million Indians, equivalent to approximately $12 \%$ of the country's overall retail intake. Retail leads to approximately $40 \%$ of India's production and $10 \%$ of India's GDP.
Retail business has been greatly affected by the lockdown to limit the risk of COVID-19 in the region. Most supermarkets have been shut down throughout the country, except for stores selling vital food and groceries, clothing (including saris), electronics, cell phones, furniture, appliances, etc. Virtually all shops are closed. Nongrocery/food retailers are announcing revenue declines of 80 to 100 percent. Also, retailers with essential goods face losses because they cannot sell non-essential products, which would give them greater profits.

Around $85 \%$ of retail costs are fixed costs, which brings retailers under a range of financial stresses. The business faces significant funding problems that can lead to unemployment on a large scale. The industry's revenue stream has come to a halt, whereas the fixed operating expenses stay unchanged. The Retailers Association of India, concerned with the state of affairs, surveyed retailers (including groups and nongroups) to determine their views on the effect of COVID-19 on their company and workforce. 


\section{CONCLUSION}

The key point of the crises mentioned above is that the recession had the most retail-oriented effects customer spending habits are expected to be irreversible. A long recession has a heavy effect on the buying behavior of customers. It takes much time for customers to stop purchasing, sales, and rehabilitation. That means retailers need to recognize that all of these habits are irreversible and must plan for a significant shift in their business model. Furthermore, the shift in behavior becomes less lasting as problems are handled easily, and customers can only re-start when they have to go shopping. Both food and drink have seen steady recovery at the end of the depression. However, rebound for discretionary categories such as clothes took time after the recession. In India, the authors expect that similar trends of recovery will emerge depending on the time of the crisis. Since COVID-19 has a medium-term effect on customer investment and will increase online spending, relevant, inexpensive categories and greater online penetration are expected to rebound more rapidly. The current study found that employee well-being and government policies have a significant positive impact on retailer performance. In contrast, customer and brand protection, use of technology, and supply chain have a significant positive on retailer performance.

In the present scenario, unorganized supermarket and district Kirana appear to be the winners. This paves the way for shops to be found in the future and further. Digital shopping continues to expand. In several markets, the recession leads to restructuring, and the retail sector will have an equal share of the effect (this time will be difficult to endure for smaller consolidated or financially constrained retailers) with few large retailers with a distinct premium plan. Retailers are compelled to worry about what they're all like when they enter places where they never went to float before during the ongoing recession. Some of these peripheries can continue to become their core.

Retailers are compelled to worry about what they are all like when they enter places where they never went to float before during the ongoing recession. Some of these peripheries can continue to become their core. Following demonetization, COVID-19 is a further catalyst for India's digital payments, with the public refusing cash transactions out of fear or comfort. In general, this should remind organizations that such an unforeseen event will occur anywhere and may involve strategic preparation if firms want to continue to help their clients through a period of interruption.

\section{AUTHOR CONTRIBUTIONS}

Conceptualization: Amgad S.D. Khaled, Eissa A. Al-Homaidi, Abdulmalek M.M. Saeed.

Data curation: Nabil Mohamed Alabsy, Eissa A. Al-Homaidi, Abdulmalek M.M. Saeed.

Formal analysis: Amgad S.D. Khaled.

Investigation: Amgad S.D. Khaled, Nabil Mohamed Alabsy, Eissa A. Al-Homaidi, Abdulmalek M.M.

Saeed.

Methodology: Amgad S.D. Khaled, Eissa A. Al-Homaidi.

Project administration: Nabil Mohamed Alabsy, Abdulmalek M.M. Saeed.

Resources: Nabil Mohamed Alabsy.

Software: Nabil Mohamed Alabsy, Abdulmalek M.M. Saeed.

Supervision: Amgad S.D. Khaled, Nabil Mohamed Alabsy.

Validation: Amgad S.D. Khaled, Eissa A. Al-Homaidi.

Visualization: Nabil Mohamed Alabsy, Eissa A. Al-Homaidi, Abdulmalek M.M. Saeed.

Writing - original draft: Nabil Mohamed Alabsy, Eissa A. Al-Homaidi.

Writing - review \& editing: Amgad S.D. Khaled, Abdulmalek M.M. Saeed. 


\section{REFERENCES}

1. Blankson, C., \& Kalafatis, S. P. (2004). The development and validation of a scale measuring consumer/customerderived generic typology of positioning strategies. Journal of Marketing Management, 20(1-2), 5-43. https://doi. org/10.1362/026725704773041113

2. Business Today. (2020). Coronavirus impact: jobs take a hit; Indian retailers see revenue slide. Retrieved from https://www. businesstoday.in/current/economy-politics/coronavirus-impactjobs-take-a-hit-indian-retailerssee-revenue-slide/story/399070. html

3. Carpenter, D., Maasberg, M., Hicks, C., \& Chen, X. (2016). A multicultural study of bio- metric privacy concerns in a fire ground accountability crisis response system. International Journal of Information Management, 36(5), 735-747. https://doi.org/10.1016/j. ijinfomgt.2016.02.013

4. Deng, S., Wang, W., \& Chao, Y. (2020). Will consumption rebound after the COVID-19 pandemic? 1 A structural equation modeling research based on the psychological arousal theory. https://doi. org/10.31234/osf.io/ch72a

5. Dennis, C., Alamanos, E., Papagiannidis, S., \& Bourlakis, M. (2015). Does social exclusion influence multiple channel use? The interconnections with community, happiness and wellbeing. Journal of Business Research, 69(3), 10611070. https://doi.org/10.1016/j. jbusres.2015.08.019

6. Dolnicar, S., \& Zare, S. (2020). Coronavirus and Airbnbdisrupting the disruptor. https://doi. org/10.31235/osf.io/t9n6q

7. Evans, O. (2020). Socio-economic impacts of novel coronavirus: The policy solutions. BizEcons Quarterly, 7, 3-12. Retrieved from https://ideas.repec.org/a/ris/buecqu/0013.html

8. Fadel, M., Salomon, J., \& Descatha, A. (2020). Coronavirus outbreak: The role of companies in preparedness and responses. The Lancet. Public Health, 20, 3005130057. https://doi.org/10.1016/ S2468-2667(20)30051-7

9. Fashion Network. (2020). India's retail sector takes a $\$ 30$ billion hit due to COVID-19. Retrieved from https://in.fashionnetwork. com/news/India-s-retail-sectortakes-a-30-billion-hit-due-tocovid-19,1203349.html

10. Fernandes, N. (2020). Economic Effects of Coronavirus Outbreak (COVID-19) on the World Economy. http://dx.doi. org/10.2139/ssrn.3557504

11. Ferry, Y., \& Leech, D. (2005). Amperometric detection of catecholamine neurotransmitters using electrocatalytic substrate recycling at a laccase electrode. Electroanalysis: An International Journal Devoted to Fundamental and Practical Aspects of Electroanalysis, 17(2), 113119. https://doi.org/10.1002/ elan.200403069

12. Field, A. (2009). Discovering statistics using SPSS: (and sex and drugs and rock'n'roll). Sage.

13. Fielding, N. G., Lee, R. M., \& Blank, G. (Eds.) (2008). The SAGE handbook of online research methods. Sage. http://epubs.surrey. ac.uk/id/eprint/790570

14. Gordon, A. V., Ramic, M., Rohrbeck, R., \& Spaniol, M. J. (2020). 50 Years of corporate and organizational foresight: Looking back and going forward. Technological Forecasting and Social Change, 154, 119966. https://doi.org/10.1016/j.techfore.2020.119966

15. Gummesson, E. (2009). The global crisis and the marketing scholar. Journal of Customer Behaviour, 8(2), 119-135. https://doi. org/10.1362/147539209X459750

16. Hair, J., Black, B., Babin, B., \& Anderson, R. (2010). Multivariate data analysis. Upper Saddle River, NJ: Pearson Prentice Hall.

17. Hamilton, R., Thompson, D., Bone, S., Chaplin, L. N., Griskevicius, V.,
Goldsmith, K., et al. (2019). The effects of scarcity on consumer decision journeys. Journal of the Academy of Marketing Science, 47(3), 532-550. https://doi. org/10.1007/s11747-018-0604-7

18. Harris, P., Dallolmo Riley, F., Riley, D., \& Hand, C. (2017). Online and store patronage: A typology of grocery shoppers. International Journal of Retail \& Distribution Management, 45(4), 419-445. https://doi.org/10.1108/ IJRDM-06-2016-0103

19. Hogan, T. P., Benjamin, A., \& Brezinski, K. L. (2000). Reliability methods: A note on the frequency of use of various types. Educational and psychological measurement, 60(4), 523-531. https://doi. org/10.1177/00131640021970691

20. Holmes, E. A., O'Connor, R. C., Perry, V. H., Tracey, I., Wessely, S., Arseneault, L., ... \& Ford, T. (2020). Multidisciplinary research priorities for the COVID-19 pandemic: a call for action for mental health science. The Lancet Psychiatry. https://doi.org/10.1016/ S2215-0366(20)30168-1

21. Huang, A., Dawes, J., Lockshin, L., \& Greenacre, L. (2017). Consumer response to price changes in higher-priced brands. Journal of Retailing and Consumer Services, 39, 1-10. https://doi.org/10.1016/j. jretconser.2017.06.009

22. Ivanov, D. (2020). Predicting the impacts of epidemic outbreaks on global supply chains: A simulation-based analysis on the coronavirus outbreak (COVID-19/ SARS-CoV-2) case. Transportation Research Part E: Logistics and Transportation Review, 136. https://doi.org/10.1016/j. tre.2020.101922

23. Janssen, C., Vanhamme, J., \& Leblanc, S. (2017). Should luxury brands say it out loud? Brand conspicuousness and consumer perceptions of responsible luxury. Journal of Business Research, 77, 167-174. https://doi.org/10.1016/j. jbusres.2016.12.009 
24. Kumar, P. (2005). The competitive impact of service process improvement: Examining customers' waitingfor experiences in retail markets. Journal of Retailing, 81(3), 171-180. https://doi.org/10.1016/j.jretai.2005.07.002

25. Makridis, C., \& Hartley, J. (2020). An Economic Analysis of the COVID-19 Effects on County Real GDP. http://dx.doi.org/10.2139/ ssrn.3559139

26. Meyer-Emerick, N. (2015). Using social marketing for public emergency preparedness: Social change for community resilience. Routledge. https://doi. org/10.4324/9781315688220

27. Miltgen, C. L., Henseler, J., Gelhard, C., \& Popovič, A. (2016). Introducing new products that affect consumer privacy: A mediation model. Journal of Business Research, 69(10), 46594666. https://doi.org/10.1016/j. jbusres.2016.04.015

28. Mowen, J. C., Licata, J. W., \& McPhail, J. (1993). Waiting in the emergency room: how to improve patient satisfaction. Journal of Health Care Marketing, 13(2), 26-33. Retrieved from https://pubmed.ncbi.nlm.nih. gov/10127062/

29. Papagiannidis, S., Boulakis, M., Alamanos, E., \& Dennis, C. (2017). Preferences of smart shopping channels and their impact on perceived wellbeing and social inclusion. Computers in Human Behavior, 77, 396-405. https://doi. org/10.1016/j.chb.2017.04.029

30. Parker, G., Pickard, J., Cookson, C., \& Pickford, J. (2020). UK to launch a business rescue package to fight coronavirus fallout. Financial Times Online. Retrieved from https://www.ft.com/ content/30931d90-6821-11ea800d-da70cff6e 4 d3

31. Pizzi, G., Scarpi, D., Pichierri, M., \& Vannucci, V. (2019). Virtual reality, real reactions? Comparing consumers' perceptions and shopping orientation across physical and virtual-reality retail stores. Computers in Human Behavior, 96, 1-12. https://doi. org/10.1016/j.chb.2019.02.008
32. Reise, S. P., Waller, N. G., \& Comrey, A. L. (2000). Factor analysis and scale revision. Psychological assessment, 12(3), 287. https://doi. org/10.1037/1040-3590.12.3.287

33. Rittichainuwata, B. N., \& Chakraborty, G. (2012). Perceptions of importance and what safety is enough. Journal of Business Research, 65(1), 4250. https://doi.org/10.1016/j. jbusres.2011.07.013

34. Schenker-Wicki, A., Ianunen, M., \& Olivares, M. (2010). Unmastered risks: From crisis to catastrophe: An economic and management insight. Journal of Business Research, 63(4), 337346. https://doi.org/10.1016/j jbusres.2009.02.021

35. Schriber, S., \& Lowstedt, J. (2019). Reconsidering ordinary and dynamic capabilities in strategic change. European Management Journal, 38(3), 377-387. https://doi. org/10.1016/j.emj.2019.12.006

36. Shah, A. K., Shafir, E., \& Mullainathan, S. (2015). Scarcity frames value. Psychological Science, 26(4), 402-412. https://doi. org/10.1177/0956797614563958

37. Sjodin, D., Parida, V., Kohtamaki, M., \& Wincent, J. (2020). An agile co-creation process for digital servitization: A micro-service innovation approach. Journal of Business Research, 112, 478491. https://doi.org/10.1016/j. jbusres.2020.01.009

38. Somason, A., \& Voyer, B. G. (2014). Emergency purchasing situations: Implications for consumer decision-making. Journal of Economic Psychology, 21-33. https://doi.org/10.1016/j. joep.2014.05.004

39. Tarki, A., Levy, P., \& Weiss, J. (2020). The Coronavirus Crisis Doesn't Have to Lead to Layoffs. Harvard Business Review Digital. Retrieved from https://hbr. org/2020/03/the-coronavirus-crisis-doesnt-have-to-lead-to-layoffs

40. Tobias, S., \& Carlson, J. E. (1969). Brief report: Bartlett's test of sphericity and chance findings in factor analysis. Multivariate behavioral research, 4(3), 375377. https://doi.org/10.1207/ s15327906mbr0403_8
41. Tsai, S. P. (2006). Investigating archetype-icon transformation in brand marketing. Marketing Intelligence \& Planning, 24(6), 648-663. https://doi. org/10.1108/02634500610701708

42. Vannucci, V., \& Pantano, E. (2019). Digital or human touchpoints? Insights from consumer-facing in-store services. Information Technology and People, 33(1), 296310. https://doi.org/10.1108/ITP02-2018-0113

43. Verhallen, T. M., \& Robben, H. S. (1994). Scarcity and preference: An experiment on unavailability and product evaluation. Journal of Economic Psychology, 15(2), 315331. https://doi.org/10.1016/01674870(94)90007-8

44. Wakefield, K. L., \& Inman, J. J. (2003). Situational price sensitivity: The role of consumption occasion, social context and income. Journal of Retailing, 79(4), 199-212. https://doi.org/10.1016/j.jretai.2003.09.004

45. Zhang, W., Gu, H., \& Kavanaugh, R. R. (2005). The impacts of SARS on the consumer behavior of Chinese domestic tourists. Current Issues in Tourism, 8(1), 22-38. https://doi. org/10.1080/13683500508668203 